\title{
Seismic Technology - Offshore Exploration and Production
}

Roberto Fainstein (University of Coimbra - Portugal) and Martin Tygel (Unicamp -Brazil)

Copyright 2018, SBGf - Sociedade Brasileira de Geofísica

Este texto foi preparado para a apresentação no VIII Simpósio Brasileiro de Geofísica, Salinópolis, 18 a 20 de setembro de 2018. Seu conteúdo foi revisado pelo Comitê Técnico do VIII SimBGf mes não ne 2018. Seu conteúdo fo revisado plo Comite seus associados. É proibida a reprodução total ou parcial deste material para propósitos comerciais sem prévia autorização da SBGf.

\section{Abstract}

Systematic offshore exploration began as a natural extension of its onshore counterpart the continental margin basins where many of the larger hydrocarbon fields were already developed with the main aspects of petroleum systems already established. The geophysical seismic technology needed for the mapping of offshore prospects progressed in tandem with marine drilling operations in this new exploration perspective of prospect mapping without geologic outcrops. This paper establishes the close relationship between seismic images evolution with hydrocarbon developments in the marine environment. As such it briefly describes the history of offshore hydrocarbon discoveries and the impact of geophysics technology for the offshore assessment of exploration and development activities, focusing into the description of the main aspects and history development of offshore drilling, offshore seismic data seismic acquisition, dat6a processing and the main aspects in the evolution of seismic structural and stratigraphic interpretation to present wide utilization of workstations with interpretive software.

\section{Introduction - Highlights of offshore drilling history}

The first well drilled offshore was in a region of oil and gas seepages near a beach north of Los Angeles where, in the tidal area, gas bubbled to the surface. This historical technical drilling challenge was met by the building of a wooden staging dock, perpendicular to the beach. A cabletool drilling rig was placed at the pier that became the earliest offshore drilling and production platform in 1897. By 1903, about 200 wells were already in operation, these continued to produce until the late 1930s decade. Another important offshore province was Caddo Lake in Louisiana. The discovery of the Caddo field goes even further back to 1870 when a water well near the lake shore produced gas and in 1911, Gulf drilled its first oil well in inland waters. Nearby, in Texas, the major Spindletop discovery in 1901 encouraged further exploration with the development of movable offshore drilling units being built in the mid-1920s. For efficient drilling offshore wooden-piled drilling platforms were mounted along with mobile steel barges that could hold some of the drilling machinery, a technique already developed in Lake Maracaibo, Venezuela by an US merchant mariner. Lake Maracaibo fields were discovered in 1917 by Shell with wells drilled on the lakeshore. Then, in 1923, Shell drilled a significant 100,000 barrel-a-day discovery leading to an oil rush to get shoreline blocks. Shell continued working the shoreline, but Gulf and Lago Petroleum drilled on the lake using wood and concrete piles to support the rigs. By this time, in the other side of the world, near Baku in the Caspian Sea, the first offshore well was drilled by the innovative rotation method on an artificially created island. The first floating drilling unit in the Caspian Sea began work in 1934 and in 1935 the first offshore metal platform was constructed. These earlier episodes of offshore drilling operations were directed almost entirely by drilling engineers with limited advice from geologic field mapping already extensively performed in most of the world's onshore regions.

In the Gulf of Mexico (GoM) the first successful well was the Creole well drilled by Superior Oil in 1937, and the first well drilled offshore Texas was drilled in 1938 in Galveston Bay by Standard Oil (nowadays ExxonMobil). In Brazil, in 1939, the CNP (Conselho Nacional do Petroleo) first drilled a well on a concrete base near Salvador, in the offshore extension of a geologic mapped feature generated by Professor Ben Barnes, that discovered Dom João Field.

After the Second World War, technological achievements accelerated, in 1945 the first US offshore lease sale took place and by 1950 there were about 50 exploratory wells in the Gulf of Mexico. Jack-up rigs were established, and by the end of the decade the first drill ship was launched. The Safaniya oil field, discovered in 1951 in the shallow waters of the Arabia Gulf, is still considered the largest offshore oil field in the world. Meanwhile in the South Atlantic, Petrobras began offshore exploration in 1954, the company was destined to be the future worldwide leader in deep-water exploration. As semi-submersible units and fixed platforms (North Sea) became available, investments in offshore grew to more than $\$ 20$ billion a very large sum at that time. In 1962 the first major discovery offshore, the Anguille oil field off Gabon was effected. The North Sea major offshore province came about with the discovery of Ekofisk in 1969 by Phillips Petroleum. In Brazil the first offshore success came with the drilling of Guaricema in 1968, and the first large discovery made by Petrobras, the Namorado Field (Baccocoli et al., 1984), was drilled in 400 meters of water depth on Campos Basin. In 1975 the Hibernia Field was drilled in the Grand Banks off New Foundland. By mid of the 80's decade offshore production accounting for the fields in the Caspian Sea, Arabian Gulf, Gulf of Mexico, North Sea and South Atlantic (Brazil, Gabon and Nigeria) exceeded $15 \mathrm{MMb} / \mathrm{d}$ or $25 \%$ of the world's total production. Recent success in shallow waters was the discovery in year 2000 of the Kashangan Field on Caspian Sea, the second largest offshore field in the world. A technological achievement was the drilling by BP in.1998 of an extended reach well beyond $10 \mathrm{~km}$ on Wytch Farm going from the coast line into North Sea. In addition to the established offshore regions, state- of-the-art exploration programs are presently underway in diverse areas of the world such as in offshore Middle-East, Mediterranean Sea, Black Sea, India, Far East Archipelago, offshore Australia, south GoM - Mexico, conjugate areas of the transform margin offshore Nigeria and offshore Suriname, and the austral basins offshore Argentina, Namibe, South Arica.. 


\section{Offshore Deepwater Basins - Plate Tectonics}

The evolution of the major deep-water salt basins were controlled by plate-tectonic events associated with the early rifting of the GoM and the South Atlantic. These events have imprinted their character on specific basin evolution and generally are divided into three distinct stages: a) pre-rift, b) rift and c) post-rift. In the South Atlantic the Albian-Aptian salt basins evolved north to the Rio Grande Rise - Walvis Ridge volcanic highs and south to the equatorial fracture zones (Bryant et al; 2012). By and large most of the important deep-water fields worldwide are situated in the salt basins, these include fields with mostly turbidite reservoirs in the post-salt and sub-salt (GoM) post-rift and mostly microbialite reservoirs in the syn.rift pre-salt (Fainstein and Krueger, 2005; Fainstein and Mohriak, 2015). Still, in the transform margin Gulf of Guinea, significant discoveries have been made in Nigeria (Bonga and Owowo) and in Ghana (Jubilee).

\section{Deepwater Drilling - Seismic Technology}

The modern era of offshore drilling was launched by Petrobras with an extraordinary program in the deep-water salt basins of the South Atlantic. Similar programs were carried out, by Shell and BP, in the Gulf of Mexico (GoM), these now in tandem with the great progress achieved in seismic technology. Giant deep-water fields, Albacora and Marlim, were discovered in the Campos Basin in 1984 and 1985 , opening the modern phase of deep-water search. Yet, these initial deep-water drilling were still based on prospects generated with 2D seismic, as were the drilling in the North Sea and Gulf of Mexico. By 1988 the advent of multiple parallel computing enabled the processing of large volumes of 3D data that from then on guided drilling operations. Mars and Diana deep-water fields were discovered in the Gulf of Mexico mini-basins, Offshore operations landmarks were the first deep-water sub-sea production tree installed by Petrobras in 1993 at water depths of 1,800 meters and the first producing floating unit installed at the Auger Field in the GoM. The trend of deepwater discoveries in the South Atlantic continued when the giant Dalia-Girassol turbidite channel reservoir complex was discovered off the coast of Angola (Bouchet et al., 2004). In 1997 another giant turbidite discovery was made in Brazil the Roncador field. Thunderhorse, one of the largest deepwater fields in the Gulf of Mexico, was discovered in 1999 in the Mississipi Canyon in turbidite reservoirs of the Upper Miocene. This was followed by discoveries of $\mathrm{Na}$ Kika in 2004 and Tiber in 2009. Deepwater production in GoM exceeds shallow water production with Shell and BP being the largest operators.

In Brazil ANP (Agência Nacional do Petróleo) was established in 1997 promoting several bid rounds. The Brazil 99/2000 seismic program was the largest 2D and 3D seismic acquisition multi-client deep-water program in the world. These data led to the discovery of several large fields in the North Campos Basin mini-basins and also led to the discovery of the Tupi pre-salt oil field (Formigli, 2007), the first giant pre-salt oil field in the South Atlantic. Since several other pre-salt fields were discovered in minibasin UDW clusters of the North Santos Basin, among these the Libra oil field now under development. Salt basins off Brazil are the best deep-water play in the world.

\section{Offshore Seismic Surveys}

The early offshore seismic surveys were made in shallow water using adaptations of land analog equipment. The first trial took place in 1938 when a Shell crew utilized fishing boats, one for shooting and two for recording, and did a test survey four miles off the Louisiana coast in 65 feet of water. Without accurate navigation, the crew had to rely on spotters on the beach who triangulated the boats positions and communicated via radio. Seismic source was a stick of dynamite lowered into the water, and the reflected amplitudes were picked up by waterproof geophones attached to a steel plate seated on the seafloor. Recorded amplitudes had limited dynamic range.

Following World War II, GSI (Geophysical Services Inc.) built transistorized recording equipment and formed Texas Instruments. It was only by the mid-1950s that seismic signals started to be recorded in magnetic tape. Changing from paper to tape records launched analog processing development the new way for seismic data acquisition and processing. Yet, the greatest advancement in seismic acquisition and processing was made conceptually by W. Harry Mayne invention of the common-depth-point (CDP) layout that enabled the stacking of seismic amplitudes. Mayne's invention was profound and continues to be the main signal-to-noise-enhancing technique is an industry standard widely employed in $2 \mathrm{D}$ and $3 \mathrm{D}$ continuous subsurface coverage. Cecil Green, who was also a founder of Texas Instruments, once reminisced that geophysics was "a perfect combination of technology and people. The high demands of science breed integrity, and modesty as well, Seismic principles developed by these pioneers revolutionized the search for hydrocarbons. In the offshore realm seismic is ab unique tool that enables accurate imaging of the sub-surface.

\section{Digital Technology - Offshore 3D surveys}

During the 60's decade digital instruments began the recording of seismic amplitudes, this at the same time that marine seismic surveys became the main tool for the mapping of offshore prospects. Digital instruments and CDP stack made possible the remarkable progress of modern petroleum seismic technology and made also an impact into the evolution of information technology itself (Robinson and Treitel, 1973). With digital technology, seismic signals detected by hydrophones could be scanned by multi-vibrators at millisecond intervals and recorded by analog to digital converters as binary digits in. formatted tape for processing. Early on seismic sections were correlated by hand to sonic logs to evaluate prospects. With computer technology this procedure became automated. Complete digital gathering and processing systems were developed, and the amount of subsurface information available increased dramatically, with seismic database management becoming another branch of the industry. 3D surveys revolutionized the petroleum industry, the first 3D seismic survey was shot in 1967 followed by several research experiments that were conducted by company consortiums such as conducted in 1972 at the Bell Lake in New Mexico. 3D-seismic technology, that initially was applied to characterize reservoirs, has now taken over the entire cycle of offshore 
exploration, development and production operations. 3D seismic resolution makes it possible to produce accurate structural and stratigraphic mapping of prospects and of field development, models of reservoirs and to monitor fluid movement in reservoirs as these are developed and produced. These capabilities have been made possible by the extraordinary advancements in seismic data acquisition, processing, and interpretation that have both improved accuracy and reduced turnaround time. Furthermore 3D data-acquisition time has reduced the price of 3D data and dramatically increased the amount of data available. Reliable digital recording instruments constant improvement in streamers quality, configurations with ever more streamers per swath, accurate satellite navigation processing, and onboard quality control and seismic data processing are now industry standards. Marine seismic vessels used for 3D acquisition have, on average, six to eight streamers, modern vessels can tow in actuality up to 20 streamers simultaneously.

\section{Seismic Data Processing Work-Flows - Interpretation}

By the early 1970s, the industry had developed suites of a data-processing algorithms (Lindseth, 1982) that contained programs for offshore multichannel processing, true amplitude recovery (Schleicher, Tygel, Hubral, 2007), velocity filtering, velocity analysis, CDP stack statistical and coherent noise reduction, deconvolution, seismic migration and seismic inversion. These processing accomplishments and the continuous improvements in data acquisition collection mightily advanced seismic prospecting by several levels yet imaging methods were still 2D based.

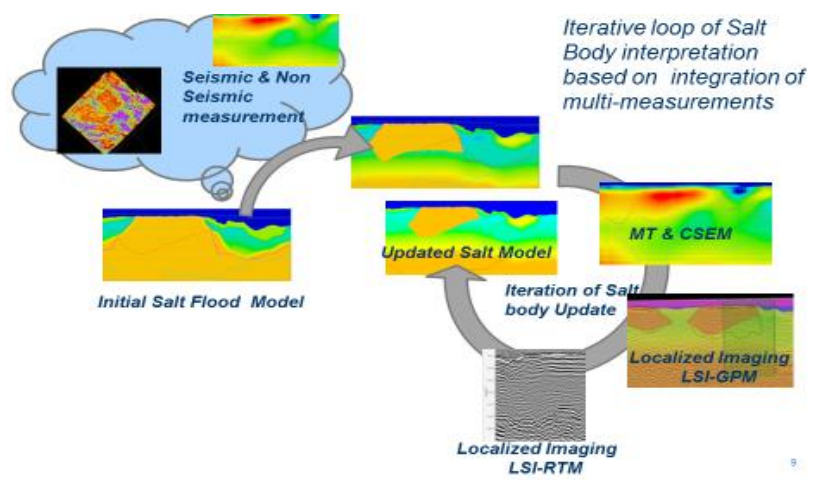

Figure 1: Interactive reverse time/depth migration model seismic imaging workflow accounts for an initial sediment model that is interactively constrained by salt floods and interpreted velocities model building. :

The modern processing algorithms came to fore with the advent on multiple parallel computing in the 80 's decade and its continued evolution into contemporaneous seismic data processing. State-of-the-art processing includes rock physics analyses, differentiated anisotropic 3D depth migration, broadband processing and seismic inversion. Multiple parallel computing enables imaging of rapid lateral changes in the sub-surface, these images distorted by time processing. Depth migration investigates several velocity models 3D depth migration (Gelius and Tygel, 2015) is emerging as a truly interpretive data-processing method that is closing the gap between geologists, geophysicists, drilling and production engineers. Interpretation of data with $3 D$ interactive workstations has played a key role in the widespread acceptance of 3D-seismic data. The amount of seismic data to be interpreted per survey has increased dramatically, placing a direct premium on efficiency in the interpretive process. There are an abundance of data that exceeds the interpretation capabilities. The logical next sequence therefore shall come about from machine learning and advanced methods of $3 \mathrm{D}$ visualization. With

Visualization 3D-seismic interpretation has become more efficient and accurate as large amounts of data may be integrated into displays through the data New production wells may be planned from inside the reservoir and the effects of any changes experienced in real time.. Furthermore, miniaturization progress now took over in describing seismic interpretation technology this with Windows based systems that add versatility and precision to the study of deep=water reservoirs. With the economies of scale brought about by 3D seismic technology, offshore exploration is now focused on the search for deep-water and ultra-deep-water reservoirs and for hidden not discovered shallower water features. Increased interest also is on improving technologies to optimize recovery in existing fields. Seismic technology therefore is now a tool extensively utilized for production and in exploration work.

\section{Shear Waves - 4D Seismic - Seismic Attributes}

Offshore shear waves multicomponent technology enabled the interpretation of reservoir fluids through the comparison with $P$ waves seismic. $P$-waves, the industry standard seismic exploration, are influenced not only by rock frame properties but also by the nature of the fluid in the rock pores. S-waves, on the other hand, are insensitive to the type of fluid in sediment. Multicomponent imaging can be effectively used to detect gas chimneys and to detect fractures and stratigraphic traps Initially cumbersome the seismic acquisition technology through ocean-bottomcable (OBC4C) has progressively recorded waves in deeper waters. OBC acquisition has become competitive with streamer operations in water depths of up to more than 1,000 meters and the future outlook is very promising. By the same token, time-lapse seismic or 4D seismic (Fainstein and Matos, 2004) consists of a series of 3Dseismic surveys repeated over time to monitor how reservoir properties (such as fluids, temperature, and pressure) change throughout the productive life. Fluid movements in reservoir-monitoring also with shear waves

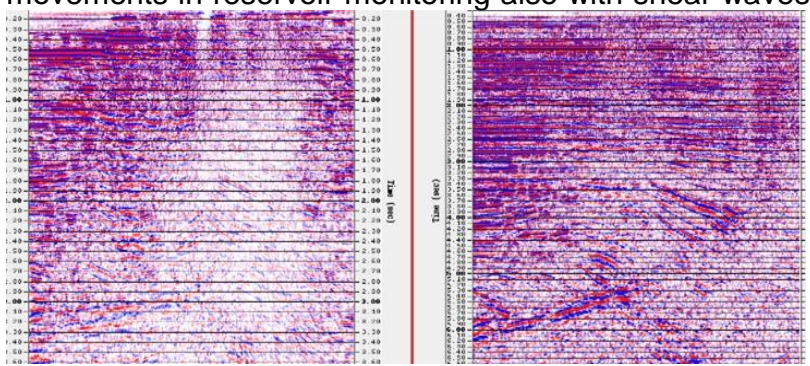

Figure 2: Shear and Cpm[ressional waves comparison interpretation enabbling fault mapping in GoM and associated gas chmney 
Therefore, imaging of the full wave-field includes both shear and compressional waves (S- and P-waves, respectively) to capture rock properties between wells, will add further value to seismic as a production tool.

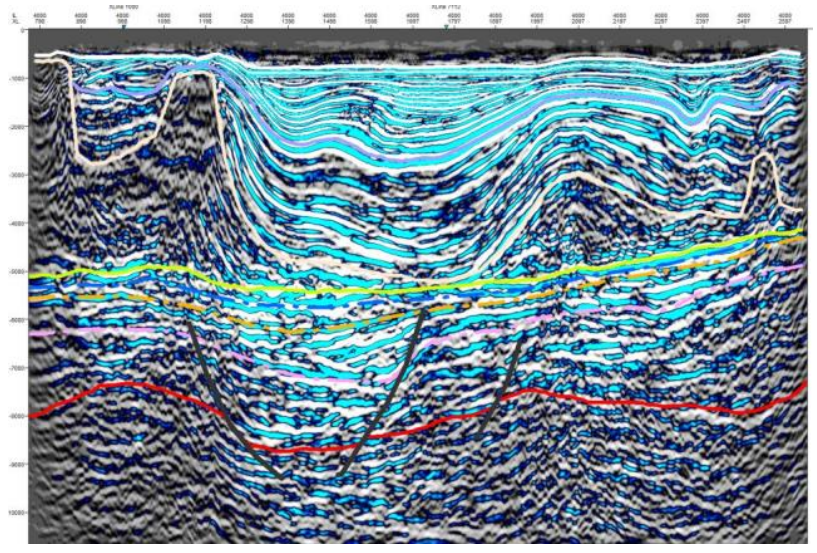

Figure 3: Seismic RTM migrated image processed with a geometric attribute so as to resolve accurately layered evaporite sequence in mini-basin flanking semialochtonous salt feature. Lacustrine syn-rift under base of the salt displays pinch-out terminations.

\section{Conclusions}

Although the initial development of offshore drilling technology centered around the exploration of shallow waters of promising extension of continental margin basins, its more mature present phase develops in tandem with seismic that oversees all aspects of drilling and development and recovery enhancements of offshore hydrocarbon fields.

The outlook for modern offshore seismic workflows points out for continued progress in every sector associated with increased computer power and miniaturization. Areas of continued research for seismic imaging improvement includes new algorithms of depth migration, broadband seismic acquisition and processing (Wallick et al, 2013; Fainstein et al, 2015) shear waves inclusion in the processing workflow, rock physics and seismic inversion.

\section{Acknowledgements}

This paper is a succinct summary extract of a larger undertaking manuscript under construction on the history progress of deepwater exploration and production and its relationship with the progress in seismic technology.

\section{References}

Bacoccoli, G., Morales, R.G. and Campos, O.A.J., 1980, The Namorado Oil Field: A Major Oil Discovery in the Campos Basin, Brazil, In: Giant Oil and Gas Fields of the Decade 1968-1978, AAPG Special Volumes, p. 329-338.

Bouchet, R., Levallois, B., Mfonfu, G. and Authier, J.P., 2004, Girassol Field Optimization Development, Proceedings AAPG International Conference, Cancun

Bryant, I., Dailly, P., Dribus, J.R., Fainstein, R., Harvey, N., McCoss, A., Montaron, B., Quirk, D. and Tapponier, P.,
2012, Basin to Basin: Plate Tectonics in Exploration, in OilField Review, Autumn Issue, p. 38-57.

Fainstein, R., 2010, Seismic Signature Comparisons of Deepwater Producing Provinces, Proceedings of the 80th Annual International Meeting of the Society of Exploration Geophysicists, Denver, USA

Fainstein, R. and Krueger, A.V.A., 2005, Salt Tectonics Comparisons near Three Continent-Ocean Boundary Escarpments, Invited Paper at the MMS-Mineral Management Services, Gulf Coast International Meeting on Salt Tectonics, Houston, Texas, USA, December 05.

Fainstein, R. and Matos, M.C., 2004, Tecnologia Sísmica Moderna: A Implementação dos levantamentos 4D., Boletim da Sociedade Brasileira de Geofisics, SBGf, no.3

Fainstein, R., Miranda, F., Goodall, A., 2013, Gaussian Beam Migration (GPM) and Reverse Time Migration (RTM) Focus Imaging in the Pre-Salt Prospectivity of Red Sea, Reservoir Symposium, Schlumberger

Fainstein, R. and Mohriak, W.U., 2015, Regional investigations and hydrocarbon exploration history of the South Atlantic rifted continental margins: Development of the salt basins and of the transform margins basins without salt, Book GCSSEPM (2015), Houston. Texas

Gelius, L-J. and Tygel, M., 2015,. Migration-velocity building in time and depth from 3D (2D) CommonReflection-Surface (CRS) stacking - theoretical framework. Studia Geophysica et Geodaetica (Praha), v. 59, p. 253282.

Formigli, J. M., 2007, Pre-Salt Reservoirs Offshore Brazil: Perspectives and Challenges. Petrobras. E\&P Production Engineering. Bank of America Energy Conference, November.

Lindseth, R.O., 1982, Digital Processing of Geophysical Data: A Review, Society Exploration Geophysics, 114 pp.

Richards. M.A., Renne, P.R., Alvarez, W., DePalma, R.A. Smit, J., Manga, M., Karlstrom, L., Vanderkluysen, J.L. , Fainstein. R., and Gibson, S., 2017, Triggering of the Largest Deccan Eruptions and Other Possible Geophysical Effects of the Mw 11 Chicxulub Impact, American Geophysical Union - AGU, Fall Meeting, New Orleans, USA December 2017

Robinson, E.A. and Treitel, S., 1973, The Robinson Treitel Reader, Seismograph Service Corporation, $3^{\text {rd }}$ Edition, $428 \mathrm{pp}$

Schleicher, J., Tygel, M. and Hubral, P., 2007 - Seismic True Amplitude Imaging: Geophysical Developments, No. 12. Society of Exploration Geophysics (SEG), 354 p.

Wallick, B.P., Giroldi, L., Husam, M., Suleiman, A., Lowden, D., Elsadany, K., Mukarram, A. and Fainstein, R., 2012, A Broadband full azimuth land seismic case study from Saudi Arabia: Interpretation and inversion lessons learned, Proceedings of the $82^{\text {nd }}$ SEG Annual International Meeting, Post-Convention Workshop, Las Vegas 